\title{
Communities Inferred from the Books of Samuel in the Old Testament of the Bible
}

\author{
Wei Hu \\ Department of Computer Science, Houghton College, New York, USA \\ Email: wei.hu@houghton.edu
}

Received February $16^{\text {th }}$, 2013; revised March $17^{\text {th }}, 2013$; accepted March $27^{\text {th }}, 2013$

Copyright (C) 2013 Wei Hu. This is an open access article distributed under the Creative Commons Attribution License, which permits unrestricted use, distribution, and reproduction in any medium, provided the original work is properly cited.

\begin{abstract}
The books of First and Second Samuel are part of historical books in the Old Testament of the Bible, which appear as a single book in Jewish scriptures. These two books record the critical transition of governing system in Israel from judges to kings and from 12 tribes to a centralized state. The three major characters in these books are Samuel priest, prophet and the last judge, Saul the first king of Israel, and David the second king, a man after God's own heart. These books contain many fascinating stories that present the life of Samuel, the rise and fall of Saul, the long journal for David to become king, and the establishment of his kingdom. In this study, we constructed a sequence of social networks from these two books based on the interactions of many characters and their locations. Our aim was to apply a computational approach to identifying the communities in these networks, which summarized the interactions between the key figures and others, along with their locations. As a result, the rich information of this part of Israel history was encoded and visualized concisely through this sequence of networks of communities in time.
\end{abstract}

Keywords: Samuel; Bible; Community

\section{Introduction}

The books of First and Second belong to the historical books of the Bible that record the history of the Israel, covering the time of this nation from conquering Canaan the promise land to the loss of this land through the Babylonian exile because of their disobedience to God (Payne, 1982; Magennis, 2011). These two books trace the social transition period of Israel from loosely organized 12 tribes to a centralized monarchy in the promise land, along with the political leadership change from tribal judges to kings. They provide a natural continuation of the book of Judges reflecting from the content overlapping between the start of the First Samuel and the end of the book of Judges. The time of the judges was a chaotic era in the history Israel since there was a repeated pattern of rebellion, oppression, and deliverance. In those days there was no king in Israel, but every man did that which was right in his own eyes (Judges, 17: 6). When Samuel, their prophet, priest, and the last judge, was quite old, the Israelites demanded a king, similar to the kings of the surrounding nations. However, the whole purpose of God creating the nation of Israel is to make this nation to be unlike all other nations (Exodus, 19: 5-6), as God Himself was the ruler, king, and God of Israel. Moses predicted Israel's desire for a human king in (Deuteronomy, 17: 14-20), but the human kings must serve as representatives of God's kingship over Israel.

The unity of contents of the First and Second Samuel suggests these two books are one book in reality as seen from the original Hebrew text (Gordon, 1999). Further, such division appears in the other books of the Bible such as First and Second
Kings and First and Second Chronicles. These books were named after Samuel, because his life formed the foundation of First Samuel and he was a partial author of the book. Samuel was not merely an editor and a character of this book, but the author of the history of this critical period of Israel, who played a pivotal role in rise of kingship of Israel (Tsumura, 2007). These books are not a narrative of historical events solely, but rather to elucidate the significance of the divine guidance of the nation Israel, revealing God is the real maker of human history.

These two books primarily chronicle the life of Samuel (1 Samuel, 1: 12), the reign of Saul (1 Samuel, 13: 31), and the reign of David (2 Samuel), since they were essential in the establishment of the monarchy. In particular, these books give a comprehensive account of the life of David, a man of faith even while a man of weakness, as illustrated from his victories and struggles and his trust and reliance upon God. As the youngest of the eight sons of Jesse, David was born in Bethlehem and served as a shepherd during his childhood. Besides being a great king, David was also well known as a great psalmist as well as a great warrior. The description of David in the Bible, as a man after God's own heart (1 Samuel, 13: 14), is more detailed than any other Bible character except Jesus Christ. Furthermore, the name David is the third most often used name in the whole Bible, with Moses and Abraham being first and second respectively. In the New Testament, Jesus is described as a "descendant of David according to the flesh" (Romans, 1: 3) according to God's Davidic covenant recorded in (2 Samuel, 7).

The birth of Samuel was God's answer to his mother's faithful prayer. From the tribe of Levi, Samuel was the maker of 
Israel kings and played a key role as God's messenger and leader, who found and anointed both Saul from the smallest tribe of Hebrews, Benjamin, and David from the tribe of Judah. He guided Israel's transition to kingship and bridged the periods of the judges and the monarchy. In addition to these three main figures, there were three more important characters in First Samuel, who were Eli that raised Samuel and the high priest prior to Samuel, Hannah mother of Samuel, and Jonathan son of Saul. Other key figures in Second Samuel were Joab the general of David's army, Bathsheba wife of Uriah and afterward of David, Nathan the prophet, and Absalom son of David. Nonetheless, the books of Samuel were cogently organized into stories of Samuel, Saul, and David, covering approximately the time period from 1050 to 970 BC (Gordon, 1999).

The books of Samuel capture so many attractive storied occurred in the history of Israel that are among the most famous from the entire ancient world (Tsumura, 2007). To discover the patterns of interactions among so many characters in these stories, we applied a community detection algorithm to a sequence of social networks made from these books. Our aim was to gain new insight into these interesting books, as God's word is a lamp to our feet and a light for our path.

\section{Materials and Methods}

\section{Materials}

The text of the Bible used in this study is from the King James version (1611 authorized version), downloaded from http://printkjv.ifbweb.com. Because First and Second Samuel are used as data in our study, this section provides some background information about three major characters in these two books, Samuel, Saul, and David.

\section{Family of Samuel}

Hannah and Elkanah were Samuel's mother and father who lived at Ramah. Elkanah was a Levite. He had another wife Peninnah who had children but Hannah had no children at the beginning of the book of First Samuel. Samuel had two sons Joel and Abijah.

\section{Family of Saul}

Saul was son of Kish from Gibeah, in the tribe of Benjamin. His wife was Ahinoam daughter of Ahimaaz. They had four sons and two daughters. The sons were Jonathan, Abinadab, Malchishua and Ish-bosheth, and the daughters were Merab and Michal. He had additional two sons, Armoni and Mephibosheth, born from his concubine Rizpah daughter of Aiah.

\section{Family of David}

David was born in Bethlehem, in the tribe of Judah. His father was Jesse. He had eight wives: Michal, daughter of Saul, Ahinoam the Jezreelite, Abigail the Carmelite, former wife of Nabal, Maachah, daughter of Talmai, king of Geshur, Haggith, Abita, Eglah, and Bathsheba, former wife of Uriah the Hittite. David also had at least one daughter, Tamar by Maachah. He had six sons born in Hebron: Amnon by Ahinoam, Daniel by Abigail, Absalom by Maachah, Adonijah by Haggith, Shephatiah by Abital, and Ithream by Eglah. By Bathsheba, his sons were: Shammua, Shobab, Nathan, and Solomon. He had others sons born in Jerusalem by other wives.

\section{Methods}

Compared to random networks, real social networks exhibit several characteristic features such as small world, power law degree distribution, and community structures (Newman, 2010). A community in a network is a group of vertices that are densely connected inside the group but sparsely outside. In this study, we made use of Walktrap, a community detection algorithm, which relies on random walks on graphs to calculate a distance that could then be used to define the structural similarity between vertices. The advantage of the method is that this distance cab be computed efficiently. Finally, a hierarchical clustering algorithm is used to merge the vertices iteratively into communities. The intuition of this approach is that: random walks on a graph tend to get trapped into densely connected parts corresponding to communities (Pons \& Latapy, 2006).

\section{Division of First and Second Samuel into Segments}

In order to make a sequence of social networks from the books of Samuel, we divided First Samuel into three logical segments, chapters 1-8 presenting the birth and life of Samuel and serving as an important preface for this book, chapters 915 describing the rise and fall of the first king Saul, and chapter 16-31 depicting God's choice of David to be Saul's successor, and David's long journey for accession to the throne. Similarly, Second Samuel was partitioned into four segments, chapters 14 showing David's victory over the house of Saul to become king of Judah, chapters 5-10 presenting the success of David's rule as king of all Israel, chapters 11-21 telling David's sins and their punishments, and chapters 22-24 covering David's faith, thanksgiving, and sin.

\section{Social Network of First and Second Samuel}

To gain a global perspective of First and Second Samuel, we present the Meta data of the social network made from the two books, including the appearances of Samuel, Saul, and David in each chapter, the social network from these two books, top 30 vertices of highest degrees in the network, and the histogram of degree distribution of all vertices in the network (Figures 1-3). The social network of First and Second Samuel displayed three characteristic traits of a real social network: small world with average geodesic distance of vertex pair $=1.847$, power law degree distribution (histogram in Figure 3), and communities structures (Figure 2). The histogram in Figure 3 suggested that vertices with small degrees are most frequent in this network.

\section{Results}

We present the communities found in a sequence of social networks from the segments of the books of Samuel as described in Section 2. With different colors these communities visualized the interactions of different characters and their locations, thereby rendering this part of Israel history with a sequence of networks of communities in time with a sense that a picture is worth a thousand words (Figures 4-12). Additionally, to give a quick summery of the chapters in each segment, the word clouds of top 50 most frequently occurred words in these chapters are displayed next to the network of the same chapters (Figures 4-12). 

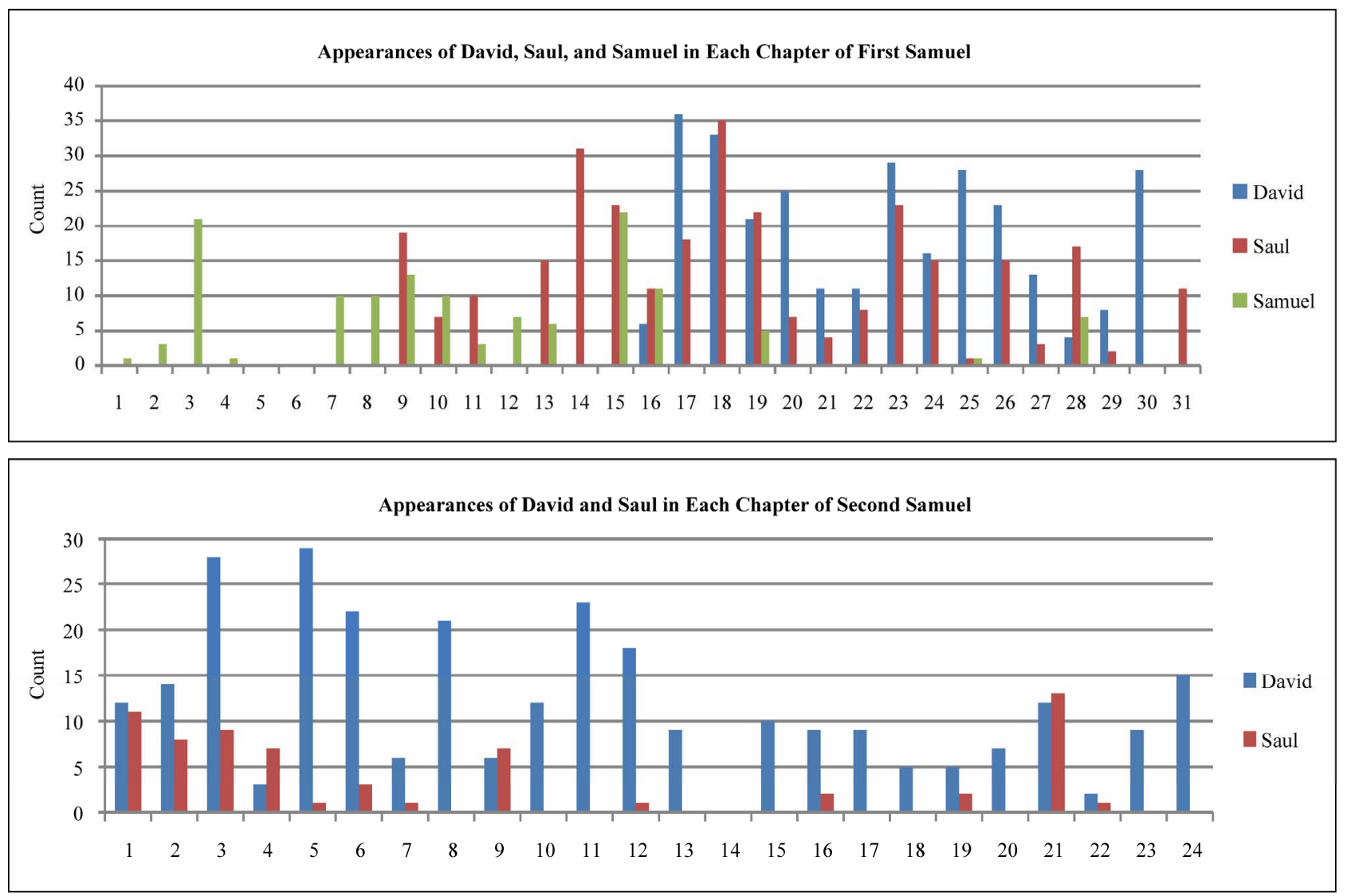

Figure 1.

Appearances of Samuel, Saul, and David in each chapter of First and Second Samuel.

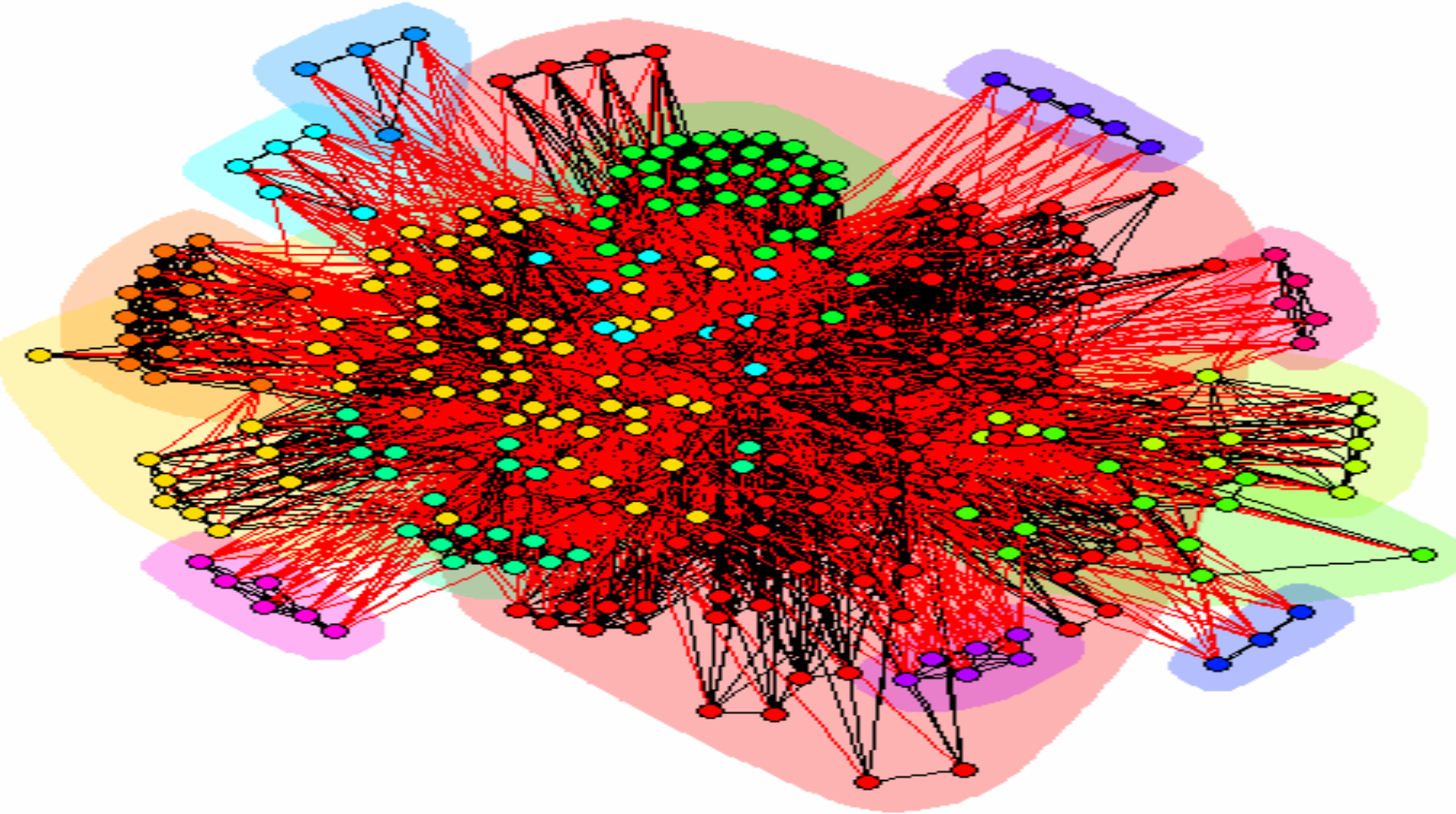

Figure 2.

Social network made from First and Second Samuel with 300 vertices, 8692 edges, and average shortest distance of vertex pairs $=1.847$. 

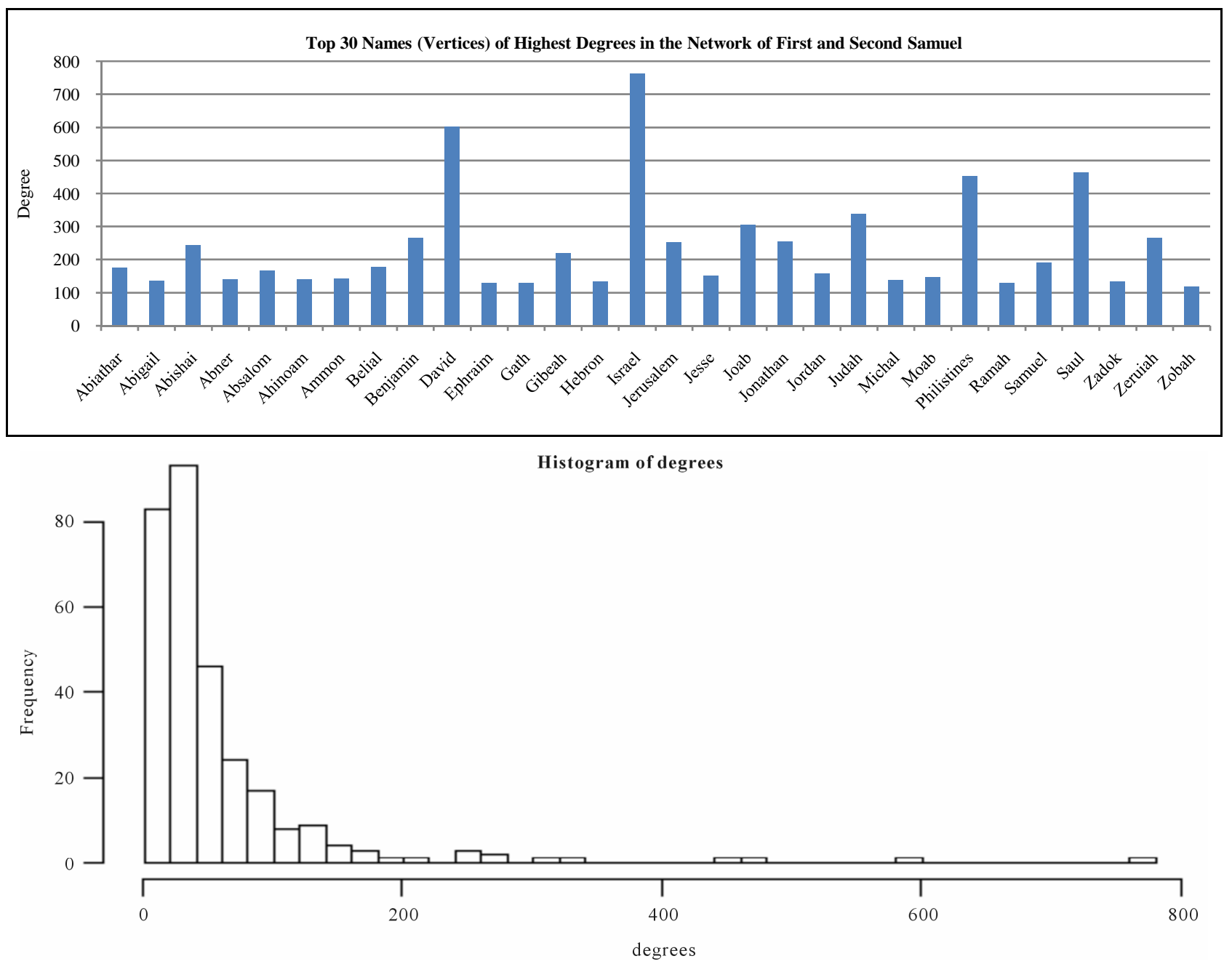

Figure 3.

Top 30 vertices of highest degrees and histogram of degree distribution with bin size $=20$ in the network of First and Second Samuel.
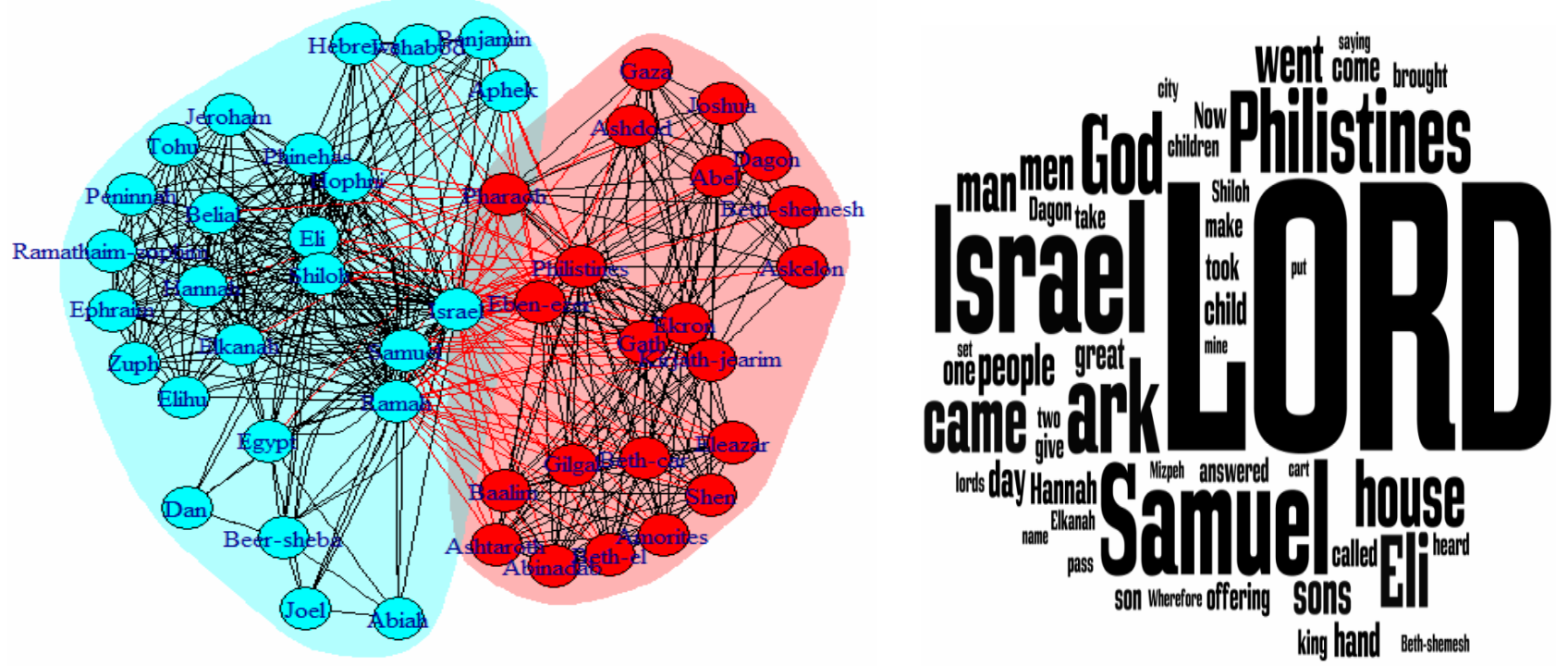

Figure 4.

Communities in the network of chapters 1-8 (left) and word clouds of top 50 most frequently occurred words in these chapters (right). 

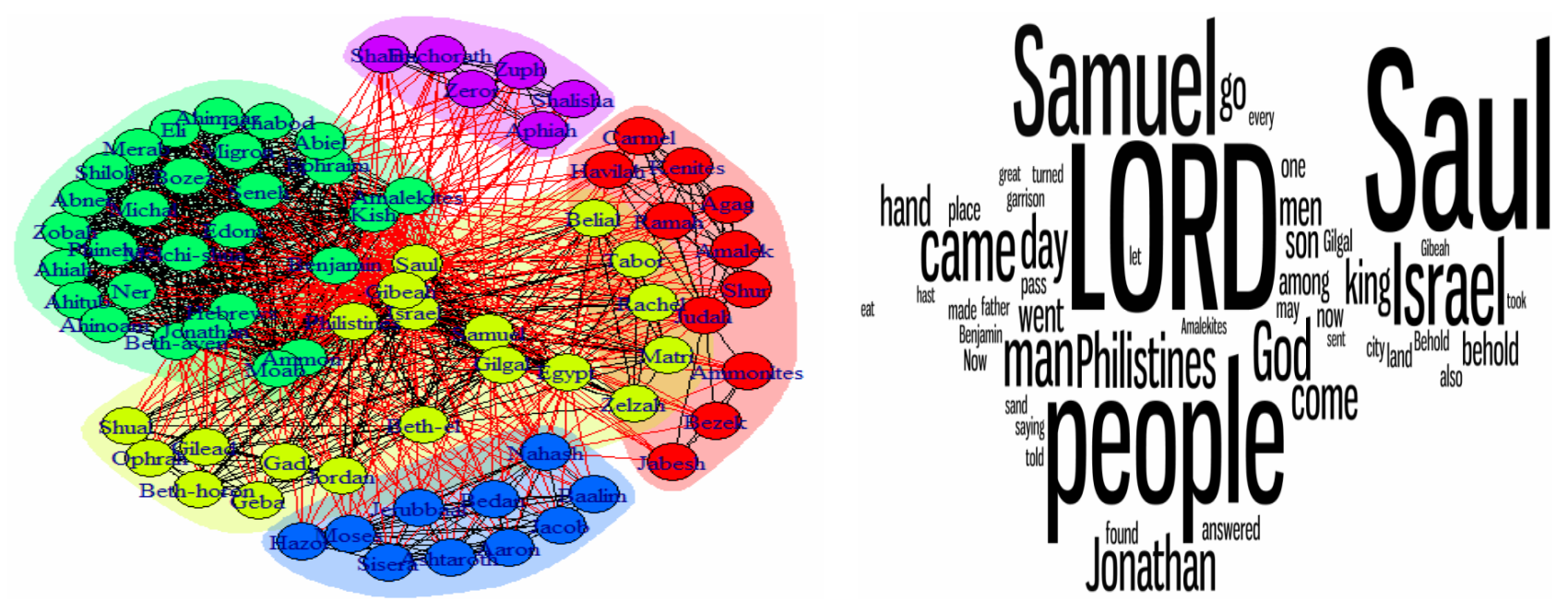

Figure 5.

Communities in the network of chapters 9-15 (left) and word clouds of top 50 most frequently occurred words in these chapters (right).
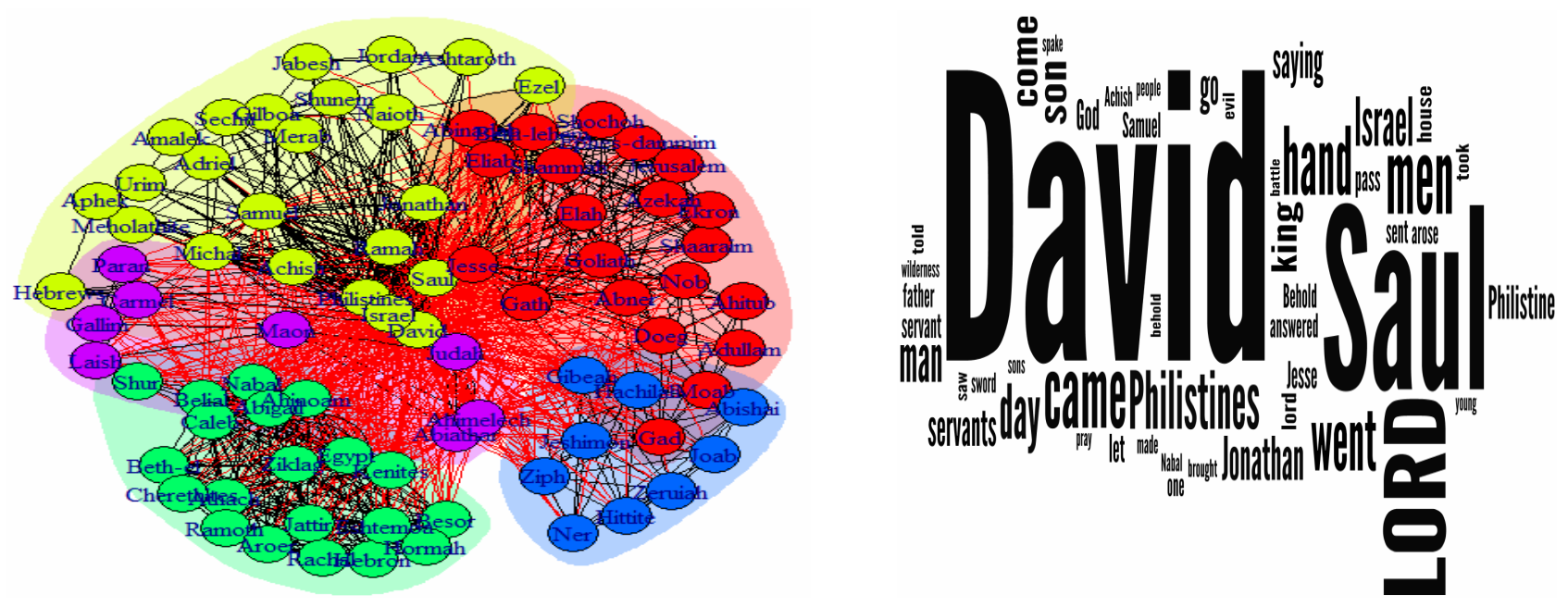

Figure 6.

Communities in the network of chapters 16-31 (left) and word clouds of top 50 most frequently occurred words in these chapters (right).
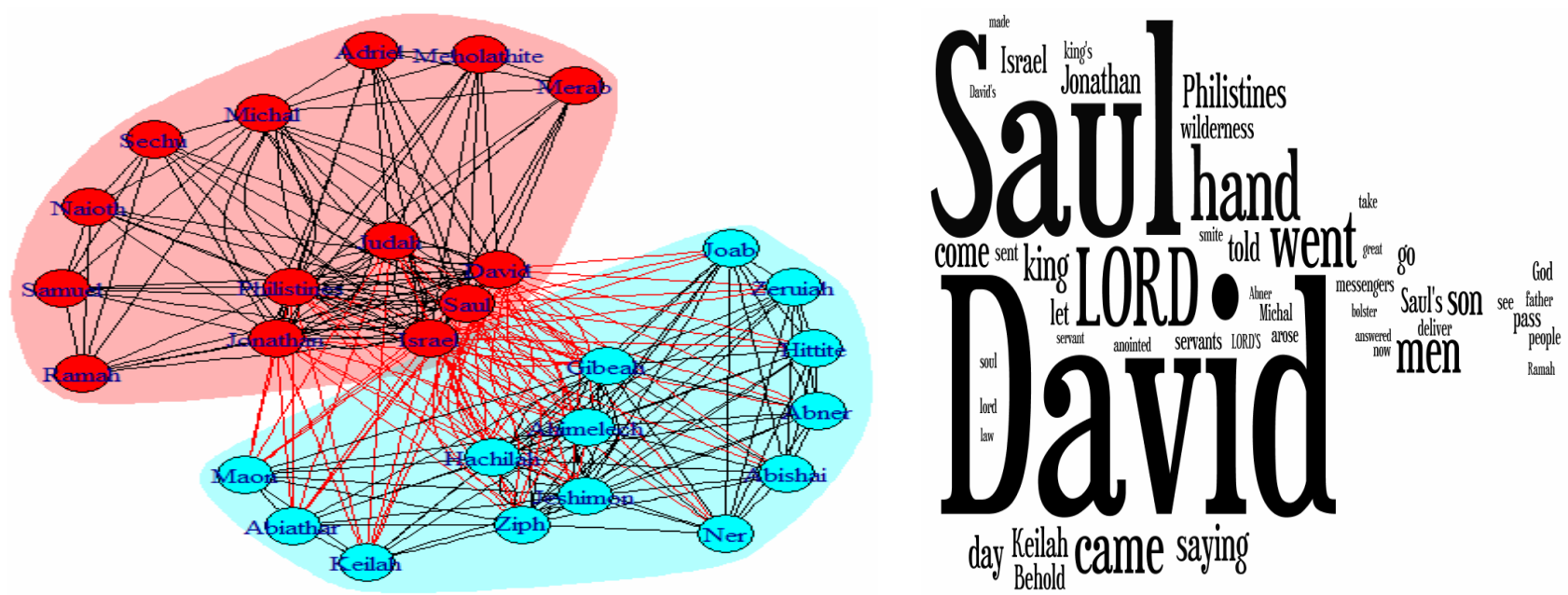

Figure 7.

Communities in the network of five chapters on Saul's Pursuit of David (left) and word clouds of top 50 most frequently occurred words in these chapters (right). 

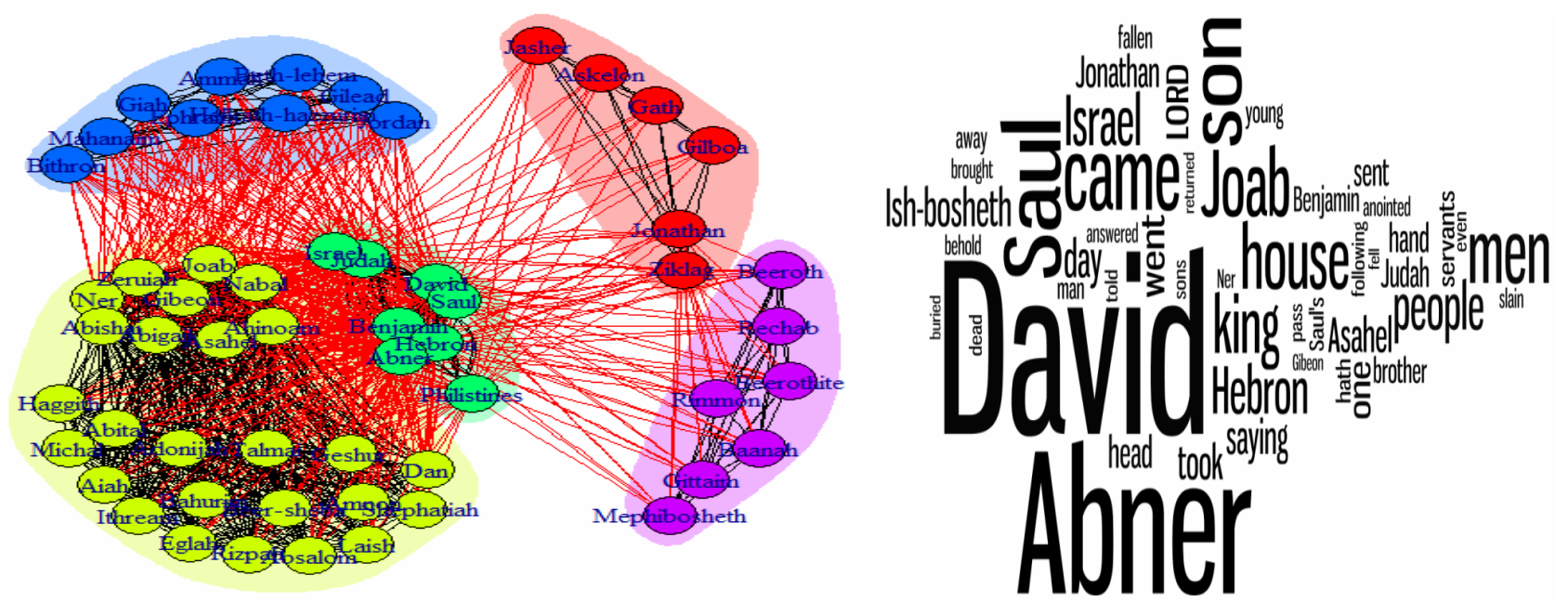

Figure 8.

Communities in the network of chapters 1-4 (left) and word clouds of top 50 most frequently occurred words in these chapters (right).
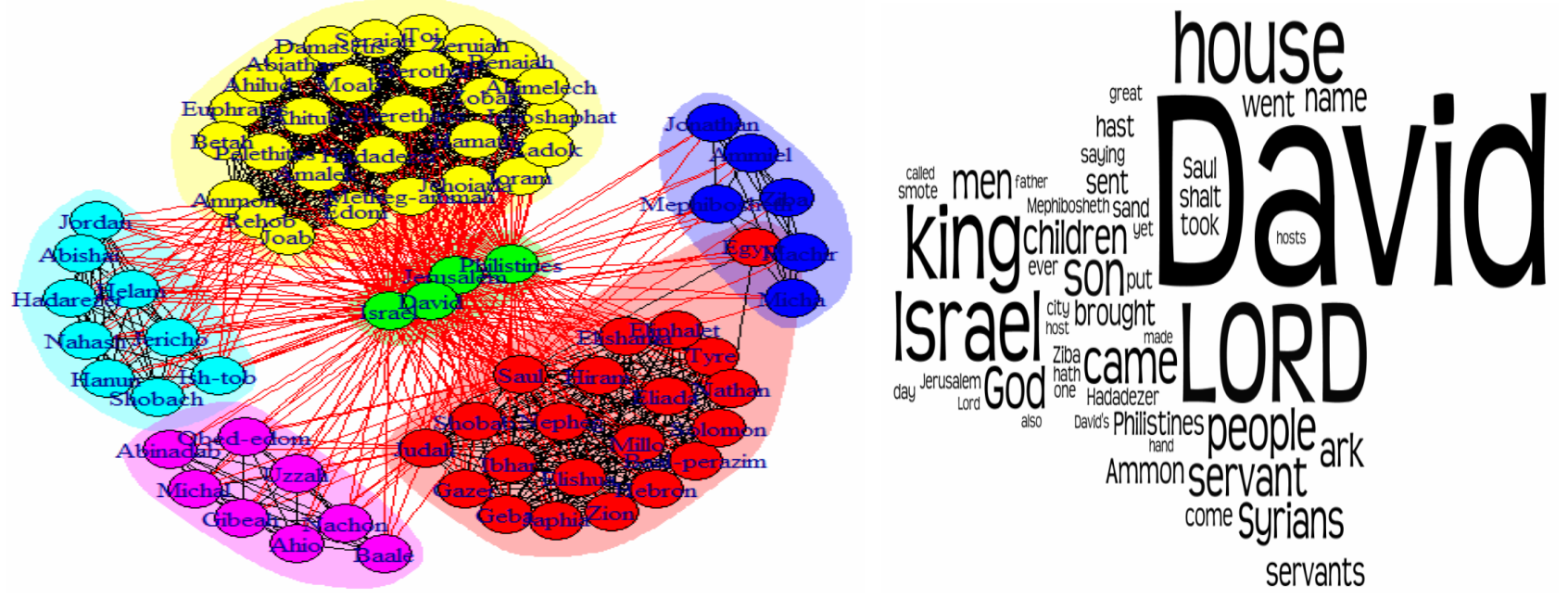

Figure 9.

Communities in the network of chapters 5-10 (left) and word clouds of top 50 most frequently occurred words in these chapters (right).
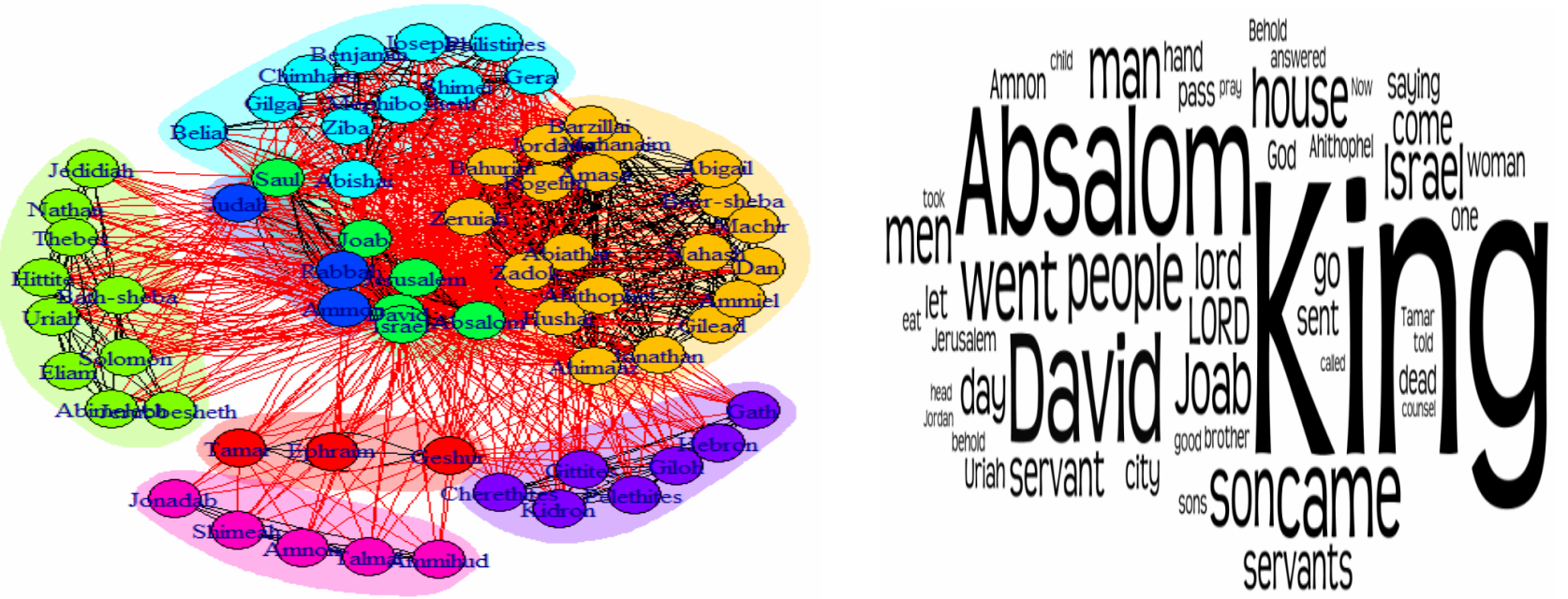

Figure 10.

Communities in the network of chapters 11-19 (left) and word clouds of top 50 most frequently occurred words in these chapters (right). 

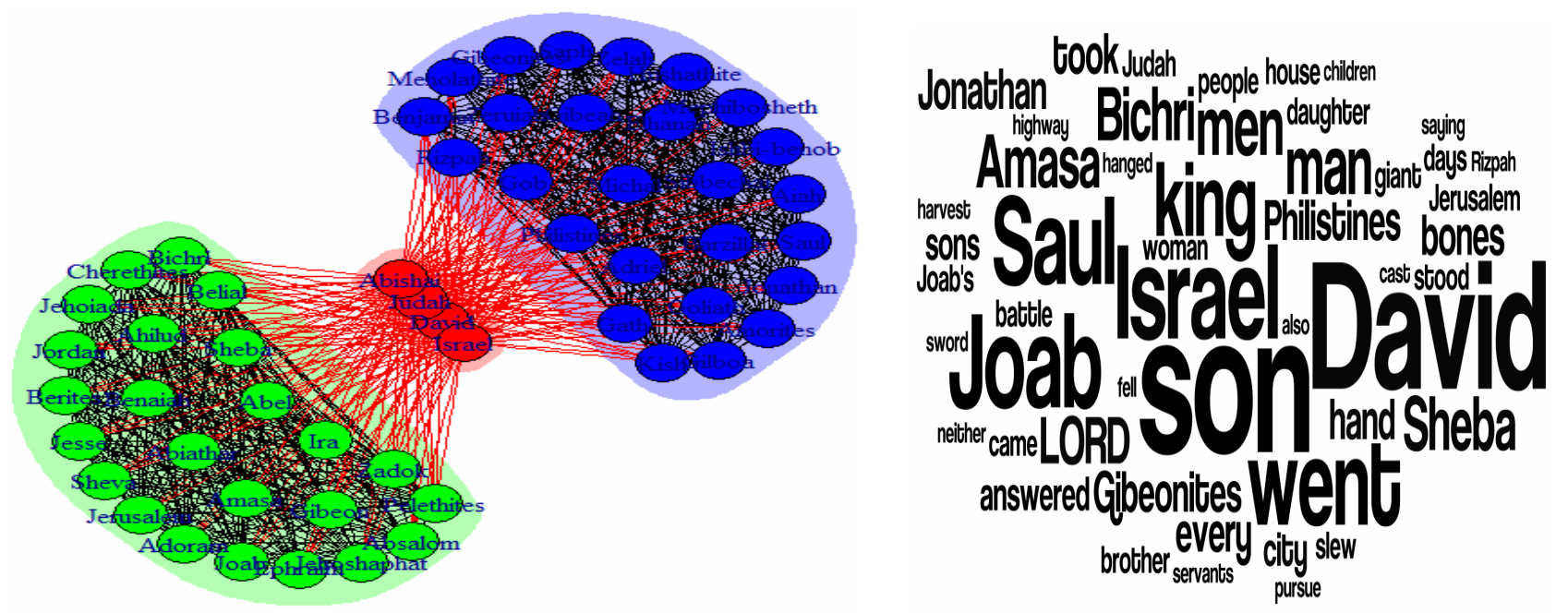

Figure 11.

Communities in the network of chapters 20-21 (left) and word clouds of top 50 most frequently occurred words in these chapters (right).
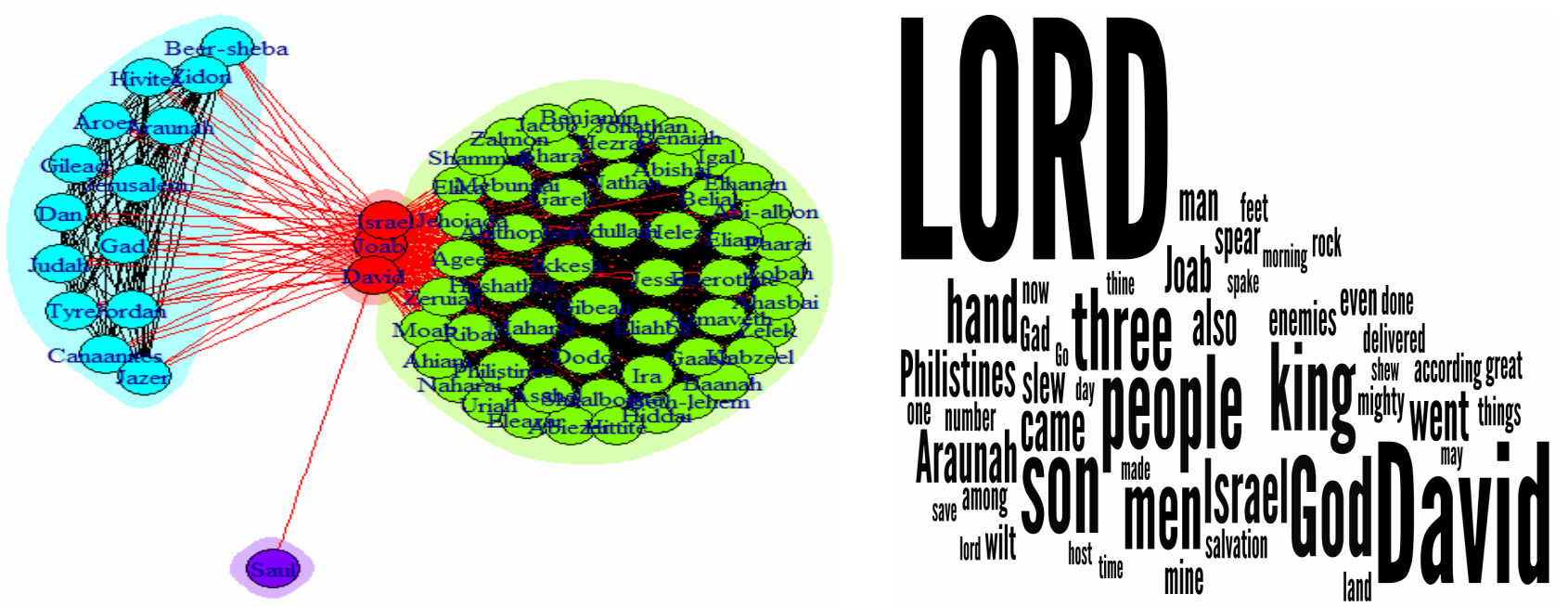

Figure 12.

Communities in the network of chapters 22-24 (left) and word clouds of top 50 most frequently occurred words in these chapters (right).

\section{Communities in the Social Networks from First Samuel}

\section{Communities in the Social Network from Chapters 1-8}

The main actor in these chapters is Samuel along with other key players such as Hannah, Eli and his two sons, Hophni and Phinehas, plus his grandson I-chabod, and Samuel's two sons Joel and Abijah. Born to Hannah and Elkanah, Samuel grew up in the temple at Shiloh, defeated Philistines at Mizpah, anointed Saul and then David, died and was buried at Ramah. The name Samuel meant "God has heard", as the child Samuel was given in answer to Hannah's prayer. These chapters present the life of Samuel, decay of the priesthood as shown by Eli and his two sons, and the Ark of the Covenant taken by Philistines when they won the battle against Israelites. But the Ark caused a disaster in the land of the Philistines and out of fear they returned the Ark back to Israel. Finally Israel asked for a human king.

Hannah was one of the two wives of Elkanah, and the other was Peninnah, who bore children to Elkanah, but Hannah re- mained childless. One day Hannah and Elkhana went from their hometown Ramah to the temple at Shiloh, where Hannah prayed to God for a child while Eli was there. Eli was the high priest in Shiloh. God gave three sons and two daughters to Hannah including Samuel (1 Samuel, 2: 21). Samuel grew up in the presence of the Lord and established a school to train young prophets in Ramah. He also died and was buried there. He was the last of the judges, after whom Saul became king of Israel.

Eli's sons, Hophni and Phinehas, were wicked and the sons of Belial (meaning worthless) although served as priests, as they had no regard for the Lord. Eli was high priest and judge over Israel, but he did not take actions to correct them. One day a man of God came to Eli to inform him of God's judgment on his household: his descendents would die at an early age, Hophni and Phinehas would die on the same day, and another family of Aaron would be given the office of high priest. Hophni and Phinehas were slain in chapter 4. Phinehas's wife gave birth to a son I-chabod. As a judge, Samuele visited the area between Bethel, Gilgal, Mizpeh, and Ramah regularly. But his 
sons Joel and Abiah who also served as judges at Beer-sheba, judged unfairly.

Encoded with so much information about the stories happened during this period, this network showed two prominent communities with different colors, with Samuel, Ramah, and Israel being at the center of the whole network (Figure 4). The vertices Eli and Philistines were at the center of their own community. Samuel was close to Ramah and Eli close to Shilon. Eli's two sons Hophni and Phinehas were close to their father and also to Belial (meaning worthless), and Samuel's two sons Joel and Abiah were close to Beer-sheba where they served as priests. Vertex Philistines was connected to their three major cities, Ashdod, Askelon, and Gaza, where the temple of Dagon was located. Philistines captured the Ark after defeating the Israelites in a battle at a location between Eben-ezer where the Israelites encamped and Aphek where the Philistines encamped. In Figure 4, Israel and Eben-ezer were in one community colored light blue, and Philistines and Aphek were in the other community colored red.

\section{Communities in the Social Network from Chapters 9-15}

The main figures in these chapters are Samuel and Saul with a focus on the rise of King Saul. Saul was anointed king by Samuel and presented to Israel, rescued Jabesh-Gilead and was acclaimed king by Israel. These chapters describe Saul's victory over the Ammonites, Samuel's farewell speech to Israel, Saul's first failure to offer burnt offering by himself instead of by Samuel as priest, Jonathan's victory and Saul's second failure to follow the Lord's command to totally destroy Amalekites and their properties, and God's final rejection of Saul due to his disobedience. The events in Chapter 15 marked a turning point in Saul's life, since God instructed Samuel to anoint David as the next king of Israel in chapter 16. Samuel did not see Saul again until he died and he told Saul that "to obey is better than sacrifice" (1 Samuel, 22), a verse still having great value in our life today.

Saul's father Kish was close to him in the network (Figure 5). Kish was son of Abiel, the son of Zeror, the son of Becorath, the son of Aphiah. The commander of Saul's army was Abner son of Ner, Saul's uncle. Saul reigned from Gibeah, his hometown. The vertex Gibeah was next to Saul in the network, showing its close relationship to Saul. His family members were in the same community colored light green. In his farewell speech, Samuel reminded Israel of God's protection to them using Moses and Aaron as their heroes. Moses and Aaron were in one small community colored blue. Saul did not obey God's instructions from Samuel by making a burnt offering by himself at Gilgal and not destroying Amalekites and their properties. Samuel, Saul, and Gilgal were in the same group, but Amalekites was close the Saul but in another group.

Eli and Shiloh were at the boundary of the community colored light green and Ramah of Samuel was at the boundary of the community colored red, reflecting their reduced importance at this time.

\section{Communities in the Social Network from Chapters 16-31}

These chapters document the decline of Saul and the rise of David through the interplay between Saul and David, one as the current king and one as the successor to Saul and the next king. The stories presented in these chapters picture a clear contrast between Saul as a king after the people's own heart and David as a king after God's own heart. They record David as an anointed king to replace Saul by God's selection, David's famous victory over Goliath, Saul's growing jealousy and quest to destroy David. Other topics included David fled from Saul, friendship of David and Jonathan, the defense of David by Jonathan and Michal, David fled to the priest at Nob, to the king of Gath, and to the cave at Adullam, Saul's revenge on the priests of Nob for having helped David, David's exile at Kehilah and in the wilderness of Ziph, David spared Saul's life in the Wilderness of Engedi, Nabal and Abigail, David spared Saul for second time, David fled to Achish, king of the Philistines, Saul went to the witch at Endor, Achish sent David back to Ziklag, David destroyed Amalekites, the death of Saul and his three sons including Jonathan.

The song of the Israelite women, "Saul has slain his thousands, and David his ten thousands" (1 Samuel, 18: 7), made Saul very jealous of David, revealing Saul's focus on earthly reputation. Instead, David placed a higher value on unseen over the seen. The flight of David against Goliath revealed their difference in character, since Saul was tall and David was just a boy at that time. David refused the physical protection of the king Saul's armor in favor of prayer and demonstrated his courage, wisdom, and faith, proving that he was the ideal man for the throne of Israel. Many of the older sons of Jesse were very impressive in their physical appearance, but God instructed Samuel to anoint the youngest son David, a shepherd boy, to be the next king after Saul.

It was a long journal for David from his anointing as a future king of Israel to eventually becoming king. During this whole period, David refused to take up the throne by forceful means but left it in the hands of God and waited for His timing. Saul pursued David into the desert where David spared his life twice, one in a cave and the other in Saul's tent while he was asleep. Still, Saul continued his pursuit. During this period, Jonathan developed a brother-like friendship with David. These chapters also record the weakness of David as he showed panics under the pressure of being pursued and lied to Ahimelech, the priest at Nob (1 Samuel, 21: 1-9), and to Achish the king of Gath (1 Samuel, 21: 10-15). These stories of Saul and David reinforced the supremacy of divine justice as articulated in Hannah's song: The proud will be humbled and the humble exalted.

Saul and his three sons, Jonathan, Abinadab, and Malchishua died on Mount Gilboa. Now Judah of David was at the center of the network, while Gibeah of Saul moved a little bit farther away from the center (Figure 6). Goliath, the champion of the Philistines, was in the red community and not very close to the vertex Philistines since this vertex is also strongly connected to other vertices. The couple, Nabal and Abigail, was in the same community colored light green and Zeruiah, David's sister, with her two sons, Joab and Abishai, were in the same community colored light blue. Samuel was in the center of the networks in Figures $\mathbf{4}$ and 5, but in this Figure 6, he was in a community colored yellow, not at the center anymore. David definitely entered the picture as a major character, along with another key player Jonathan, which was located in the center of this network. David and Jonathan were close to each other in the same group because of their friendship, and both of them were in the center. David was close to his father Jesse although they belonged to two different groups, and Jesse was connected to his other three sons, Abinadab, Eliab, and Shammah, and his hometown Bethlehem. 


\section{Saul's Pursuit of David}

This story was the most interesting one in First Samuel, which displayed the opposite traits of Saul and David. Saul was trying to kill David, but David spared Saul's life not only once but twice. Each time after learning David had spared his life, Saul cried and promised David not to kill him anymore, but Saul continued his pursuit afterwards. We singled out the chapters that described the direct contact between Saul and David during this period and summarized each chapter below.

Chapter 18: All Israel and Judah loved David, so Saul became jealous of David. One day Saul hurled a spear towards David while he was playing the harp for Saul. But David eluded him twice. Saul promised to give his daughter Merab to David as his wife but Saul instead gave her to Adriel of Meholathite as wife. Saul's son Jonathan was very fond of David and protected David. David and his men went out and killed two hundred Philistines. Then Saul gave David his second daughter Michal as his wife.

Chapter 19: Saul tried to pin David to the wall with his spear as David was playing the harp, but David eluded him again. Saul then sent men to watch and kill David, and Michal helped David to flee. David went to Samuel at Ramah and then Saul went from a great well in Sechu to Naioth at Ramah to find David.

Chapter 23: The Ziphites went up to Saul at Gibeah and said, "Is not David hiding among us in the strongholds at Horesh, on the hill of Hachilah, south of Jeshimon?” So Saul pursued David from Keilah to the desert of Ziph and then to the wilderness of Maon. When a messenger came to Saul, saying the Philistines are raiding the land. Then Saul broke off his pursuit of David and went to fight the Philistines. Abiathar the priest was with David during this time.

Chapter 24: David spared Saul's life in a cave at En Gedi.

Chapter 26: Abishai and Ahimelech went with David to the camp of Saul at night. Abner son of Ner was with Saul as his commander of the army. Saul made his camp beside the road on the hill of Hakilah facing Jeshimon. David asked Ahimelech the Hittite and Abishai son of Zeruiah, Joab's brother, to go to Saul's camp by night. When David and others went into Saul's camp, he was asleep. So David spared Saul's life again.

Because of the direct interactions between the people of Saul and those of David, there was no clear separation between the followers of Saul from the followers of David as illustrated by the two communities identified in this network (Figure 7). However, these two communities did show Saul and David as being the center of both of them.

\section{Communities in the Social Networks from Second Samuel}

Chapters 1-10 of Second Samuel detail the rise of David's kingdom. Because of the resolution limit of the community graphs, we divided these chapters into two parts, chapters 1-4 and 5-10.

\section{Communities in the Social Network from Chapters 1-4}

The last part of First Samuel marks the end of Saul's life and Second Samuel opens with more details to the death of Saul. We have to remember that Saul had hunted David for many years prior to Saul's death. Chapters 1-4 record David's lament over Saul and Jonathan who died on the battlefield of Mount Gilboa, David was anointed in Hebron as king over Judah his own tribe, Saul still had one surviving son Ish-bosheth who was crowned king over Israel, the war between the houses of David and Saul, David had six sons born in Hebron: Amnon, Kileab, Absalom, Adonijah, Shephatiah, Ithream, David asked Abner and Ish-bosheth to return his wife Michal, Joab had two brothers, Abishai and Asahel, Asahel was killed by Abner who was cousin to Saul and the commander-in-chief of Saul's army and went over to David, Joab murdered Abner for revenge, and finally Ish-bosheth was killed and the northern tribes asked David to rule the entire nation of Israel.

David, Israel, and Saul remained at the center of the network, and Saul was next to Benjamin, his tribe. Zeruiah, sister of King David, had three sons, Joab, Abishai and Asahel. David had six sons born in Hebron. All these family members of David were in the same group colored yellow. Jonathan was next to Gilboa where he and his father died. Abner was a prominent figure in these chapters as his name appeared 46 times and many David's activities occurred in Hebron while he was king over Judah, which explained the centrality of these vertices in the network (Figure 8).

\section{Communities in the Social Network from Chapters 5-10}

Chapters 5-10 include David united the kingdom and became king over Israel, David brought the Ark to Jerusalem, God's promise to David, David's victories over the enemies including Moab, Philistia, Zobah, and Syria, David's kindness to Mephibosheth son of Jonathan since David made a covenant with Jonathan, and David defeated the Ammonites and Syrians. David took Israel into several battles to win some of the promised land that had never been fully claimed.

The Davidic covenant recorded in chapter 7 is the theological centerpiece of this book. God made the house of David to prosper and in light of this the desire to build a permanent dwelling place for God arose in David. So he wanted to build a temple for worshiping God. Through the prophet Nathan, God informed David that He would not allow David to do so but his son Solomon would. Further God promised David that $\mathrm{He}$ would establish a house for David and the house and kingdom of David would endure forever before God and his throne would be established forever. God promised David that the Messiah, Jesus Christ, would come from the lineage of David and the tribe of Judah and would establish an everlasting kingdom. This promise to David was in fact the further unfolding of a previous promise God gave to Abraham in (Genesis, 15: 18). It also fulfills Jacob's promise that the scepter will never depart from Judah, David's tribe (Genesis, 49: 10).

One noticed that Saul moved from the center to a community colored red and Jerusalem became the center of this network, signaling the beginning of David's kingdom. In Hebron David reigned over Judah for seven years and six months and in Jerusalem he reigned thirty and three years over all Israel, as a result Jerusalem was at the center of this network. Judah and Hebron were in the same group colored red. Mephibosheth was next to his father Jonathan, and David showed graciousness to him due to the covenant between David and Jonathan (Figure 9).

\section{Communities in the Social Network from Chapters 11-19}

Chapters 11-21 cover David's sins and their consequences. For the sake of clear visual presentation, we divided these chapters into two groups, chapters 11-19 and 20-12. Chapter 
11-19 describe David's adultery and murder, God's punishment on David, birth of Solomon, defeat of Ammon, rape of Tamar by Amnon, death of Amnon, and rebellion as well as death of Absalom.

David committed adultery with a married woman, Bathsheba, and got her pregnant. He then attempted a cover-up. When that failed, he conspired having her husband Uirah killed. Although David repented when the prophet Nathan confronted him regarding his sins and God forgave him, He promised David the judgment: "Now the sword shall never depart from your house" (2 Samuel, 12: 10).

The consequences of David's sins affected not only himself but also his family and his nation. Up to this point, three of David's son had died, Amnon, Absalom, and the first child born to David and Bathsheba. After the death of his elder brothers Amnon and Absalom, Adonijah, the fourth son of David, considered himself to be the rightful heir to the throne and proclaimed to be king when his father was dying. He was put to death after Solomon became king of Israel as successor of David (1 Kings, 2: 13-25). Amnon Absalom, and Adonijah died not only as punishments to David, but also because of their own sins. Absalom was prominently featured in these chapters. Completely different from Solomon, Absalom committed many heinous crimes such as sleeping with his father's concubines, plotting a conspiracy to kill his father.

Absalom was a new key player in this time, since he killed Amnon who rapped Tamar, rebelled against his father, and was killed by David's general Joab in the forest of Ephraim. After Absalom had killed Amnon, he fled to Talmai, the son of Ammihud, king of Geshur, since Absalom's mother was princess of Geshur. Ahithophel was a wise counselor of David, but during Absalom's rebellion against David, he betrayed David and became an adviser to Absalom. These names were next to each other in the network. The chief figures in David's adultery, Bathsheba daughter of Eliam, Uriah of Hittite, and Nathan, were in one community along with Solomon who had another name Jedidiah given by God through Nathan.

\section{Communities in the Social Network from Chapters 20-21}

Chapters 20-21 present the rebellion of Sheba son of Bicri, a Benjamite, three years of famine because Saul and his house put the Gibeonites to death, the revenge of Gibeonites, and the defeat of Philistines. In Canaan the Philistines were strong, having battles against Israel throughout the period of the judges. However, the leadership of Samuel, Saul and then David eventually made the Philistine threat declined.

Israel, Abishai, Daivd, and Judah were mentioned in both chapters, which explained why they were at the center of this network. Saul is at the boundary of the community colored blue (Figure 11).

\section{Communities in the Social Network from Chapters 22-24}

Chapters 22-24 conclude this book with final reflections on the life of David, showing the closing phase of David's reign, his faith through his psalm of praise to God, his thanksgiving in his last words, the names of his mighty men including Uriah of Hittite, and his sin of numbering people and the resultant plague as God's punishment, his construction of an altar.

Araunah, appeared in the blue community (Figure 12), was a Jebusite whose threshing-floor in Jerusalem was pointed out to David by the prophet Gad as an ideal site for building an altar of burnt offering to God. The destroying angel, sent to punish David for his sin in taking a census of his people, was withheld from his destruction near that threshing-floor. Araunah offered it to David as a free gift, but David insisted on purchasing it at its full price (2 Samuel, 24: 24), for he could not offer to God what cost him nothing. On the same location Solomon afterwards built the temple. Joab, a central figure in this network, was killed by Solomon according to David's command (I Kings, 2: 5-6). The end of this book seemed sad for Saul as he became a single outlier in this network, but David remained in the center of the network (Figure 12).

\section{Discussion and Conclusion}

Israel started as a nation of loosely organized tribes led by priests and heroes. The books of Samuel document Israel's transition from a group of 12 tribes ruled by judges, represented by the last two judges Eli and Samuel, to a united state ruled by kings, represented by the first two kings Saul and David. Through three central figures, Samuel, Saul, and David, two obeyed and one disobeyed, they demonstrate that God reigns by adapting to human situations to accomplish His plans and purposes, regardless of their response to Him. The history of Israel proves that trusting in God would lead to victory over their enemies whereas relying on their own strength would result in failure and defeat. It is interesting to notice that Saul, David, and Solomon all served as king of Israel for 40 years.

The service of Samuel brought to an end of judges and gave hope in a humanly desirable king. Saul, a man according to human flesh, was more concerned with earthly objectives than with spiritual matters of God. On the other hand, the kingship of David, a man according to the heart of God, demonstrated the characteristics of an ideal ruler relying on God in every situation, and brought hope in the coming Messiah. The books of Samuel document many positive achievements of David as well as his transgressions and punishments, which show that God remained loyal to His promise although David at times failed the covenant. God gave David and Bathsheba the child Solomon, whom later became king of Israel. He was merciful by safeguarding David during the rebellions of Absalom and Sheba. On the other hand, David confessed his sins before God, unlike Saul who always tried to excuse his sins, which made all the difference in their life, revealing that God hates and punishes sins but loves sinners. Hannah described God in (1 Samuel, 2: 3-10) as: He brings low the boastful, arrogant, mighty, full, rich, and wicked, and in contrast He exalts the feeble, hungry, barren, poor, low, needy and godly.

Through the communities found in a sequence of social networks from the books of Samuel, we could learn the roles played by key figures such as Eli, Samuel, Saul, David and their interactions with others during each important period. The community structures discovered from this sequence of networks visualized the interesting stories occurred during this critical transition of Israel from rule by judges to rule by kings.

\section{Acknowledgements}

We thank Houghton College for its financial support.

\section{REFERENCES}

Gordon, R. P. (1999). 1 \& 2 Samuel: A commentary. Grand Rapids: 
Zondervan.

Magennis, F. T. (2011). First and second Samuel (New Collegeville bible commentary: Old Testament). Collegeville: Liturgical Press.

Newman, M. (2010). Networks: An introduction. New York: Oxford University Press.

Payne, D. F. (1982). I and II Samuel (OT daily study Bible series). Westminster: John Knox Press.
Pons, P., \& Latapy, M. (2006). Computing communities in large networks using random walks. Journal of Graph Algorithms and Applications, 10, 191-218. doi:10.7155/jgaa.00124

Tsumura, D. T. (2007). The first book of Samuel (New international commentary on the Old Testament). Grand Rapids: Wm. B. Eerdmans Publishing Company. 